\title{
AKTIVITAS HARIAN BURUNG KUNTUL KECIL (Egretta garzetta) DI PULAU SERANGAN, BALI
}

\section{DAILY ACTIVITIES OF LITTLE EGRET (Egretta garzetta) AT SERANGAN ISLAND, BALI}

\author{
M. Rheza Rizki Syahputra ${ }^{1}$, I Ketut Ginantra ${ }^{1}$ dan A.A. Gde Raka Dalem² \\ ${ }^{1}$ Program Studi Biologi, FMIPA, Universitas Udayana \\ Bukit Jimbaran, Bali, rhezadsm@gmail.com \\ ${ }^{2}$ Kelompok Studi Ekowisata \& Pembangunan Berkelanjutan, FMIPA, Universitas Udayana, Bali, sustainablebali@yahoo.com
}

Diterima 23 Januari 2017. Disetujui 24 September 2017

\section{INTISARI}

Penelitian tentang aktivitas burung kuntul kecil (Egretta garzetta) dilakukan di Pulau Serangan antara bulan Mei dan Juni 2016. Penelitian ini bertujuan untuk mengetahui aktivitas harian burung kuntul kecil pada tipe habitat berbeda yaitu laguna, mangrove dan pantai berlumpur. Penelitian pendahuluan menggunakan metode $A d$ Libitum sampling, sedangkan penelitian utama menggunakan metode scan sampling, yaitu mencatat setiap aktivitas dari kelompok kuntul kecil yang diambil secara acak dengan interval waktu 30 detik selama 2 jam pada berbagai tipe habitat berbeda. Pengambilan data dibagi menjadi 3 periode waktu yaitu pada pagi hari, siang hari, dan sore hari. Data yang diperoleh diolah secara deskriptif kualitatif dan secara kuantitatif. Hasil yang didapatkan menunjukkan bahwa dari ketiga periode waktu aktivitas kuntul kecil yang mendominasi adalah foraging sedangkan aktivitas dengan persentase paling rendah adalah agonistik. Pada habitat laguna, persentase aktivitas foraging adalah sebagai berikut: pagi 50,15\%, siang 46,62\%, sore 49,63\%. Pada habitat mangrove, persentase aktivitas foraging adalah sebagai berikut: pagi 52,46\%, siang 41,60\%, sore 50,83\%. Pada habitat pantai lumpur, persentase aktivitas foraging adalah sebagai berikut: pagi 50,18\%, siang 42,70\%, sore 49,65\%.

Kata kunci : kuntul kecil, Pulau Serangan, aktivitas harian, Bali

\section{ABSTRACT}

A study on activity of the Little Egret (Egretta garzetta) was conducted in Serangan Island, southern part of Bali between May and June 2016. The aim of this study was to find out daily activities of these birds in three different habitats: lagoons, mangrove forests and muddy beaches. Preliminary observation was conducted through Ad Libitum sampling, while the sample on the main study was through a scan sampling method. The data was collected through recording activities of the egret on interval of 30 seconds within two hours. The data collection was undertaken in three periods: morning, afternoon and evening. The colony of observed egrets was chosen randomly across habitats and time periods. Data collected were descriptively or quantitatively analysed. Results of the study showed that from the three observation periods, the egret activities were dominated by the same activities, that was foraging, but with different magnitudes or percentages. In contrast, activities with the lowest percentage was agonistic. In the lagoon area, the percentage of the activity of foraging was as follows: in the morning it was $50.15 \%$, in the afternoon $46,62 \%$, and in the evening $49,63 \%$. In mangrove areas the percentage of foraging activities was as follows: in the morning it was $52.46 \%$, in the afternoon $41.60 \%$, and in the evening $50.83 \%$. The percentage of foraging activities in muddy beaches was as follows: in the morning it was $50.18 \%$, in the afternoon $42.70 \%$, and in the evening $49,65 \%$.

Keywords : little egret, Serangan Island, daily activities, habitat, Bali

\section{PENDAHULUAN}

Kuntul kecil (Egretta garzetta) merupakan salah satu jenis burung air yang sebagian hidupnya berada di daerah perairan atau lahan basah (Elfidasari dan Junardi, 2005). Kuntul kecil termasuk dalam ordo
Ciconiiformes dan famili Ardeidae yang tersebar di seluruh belahan dunia termasuk Indonesia, di antaranya Sumatera, Jawa, Kalimantan dan Bali (Mackinnon dkk., 2010). Dari 24 spesies famili 
Ardeidae setengah diantaranya dilindungi menurut Peraturan Pemerintah No. 7 Tahun 1999 tentang pengawetan jenis tumbuhan dan satwa (Sudarsana, 2006). Kuntul kecil memiliki ukuran tubuh sekitar 55 - $65 \mathrm{~cm}$ dengan panjang sayap antara $88-106 \mathrm{~cm}$. Ukuran ini lebih besar dibandingkan dengan ukuran kuntul kerbau (Bulbucus ibis). Kuntul kecil memiliki warna bulu putih, paruh berwarna hitam, kaki hitam dan jari - jari kaki yang berwarna kuning atau hitam (Mackinnon dkk., 2010).

Indonesia merupakan negara yang menyediakan habitat mendukung bagi burung air migran ataupun penetap (residen). Salah satu habitat ini terdapat di kawasan Pulau Serangan. Pulau ini memiliki luas 481 ha. yang terdiri dari tanah tegalan seluas 394 ha, pemukiman 48 ha dan sisanya berupa dataran pasir (Trialfianty, 2013). Keberadaan perairan, dataran lumpur, laguna serta kawasan mangrove menjadikan tempat ini merupakan habitat yang sangat ideal bagi burung air, salah satunya adalah kuntul kecil ( $E$. garzetta).

Aktivitas yang biasa dilakukan burung kuntul kecil dalam kesehariannya dimulai saat keluar dari sarang, yaitu bergerak, foraging, istirahat, interaksi dengan spesies lain ataupun sesama spesies kuntul, sampai burung ini kembali ke sarangnya. Di Bali, kajian burung kuntul kecil lebih banyak pada kajian keberadaan spesies dan potensinya untuk ekowisata birdwatching (Dalem dan Subagio, 2016a; Dalem dan Subagio, 2016b; Suaskara, 2016; Dalem dkk., 2014, Wirasiti dkk., 2004; Suaskara dkk., 2010; Dalem dkk., 2003; Dalem dkk., 2011). Perlu diadakan penelitian menyangkut aktivitas harian burung kuntul kecil di Pulau Serangan, yang akhirnya menjadi tujuan dari penelitian ini.

\section{MATERI DAN METODE}

Penelitian ini dilaksanakan di kawasan Pulau Serangan, Kecamatan Denpasar Selatan, Provinsi Bali. Penelitian dilaksanakan selama satu bulan antara bulan Mei dan Juni 2016. Waktu penelitian dibagi menjadi tiga periode yaitu pagi hari (pukul 06.0o - o8.0o WITA), siang hari pukul (12.00 14.00 WITA) dan sore hari (pukul 16.00 - 18.00 WITA). Metode yang digunakan pada penelitian pendahuluan adalah metode Ad Libitum Sampling yaitu mencatat semua aktivitas yang dilakukan oleh burung kuntul kecil tanpa ada batasannya (Altmann, 1974). Dari penelitian pendahuluan didapatkan kategori aktivitas antara lain bergerak, bertengger, foraging, vokalisasi, agonistik, preening, dan berdiam diri. Metode yang digunakan pada penelitian utama adalah metode Scan Sampling. Kelompok individu burung diambil secara acak di beberapa tipe habitat (mangrove, pantai lumpur, dan laguna) yang ada di kawasan Pulau Serangan (Gambar 1). Setiap aktivitas kelompok individu dicatat dengan interval waktu 30 detik selama 2 jam pengamatan. Total waktu pengamatan selama 1 bulan adalah 180 jam. Pengamatan menggunakan binokuler dengan radius antara peneliti dengan burung maksimal $200 \mathrm{~m}$. Setelah itu data yang sudah didapat diolah secara deskriptif kualitatif dan secara kuantitatif.

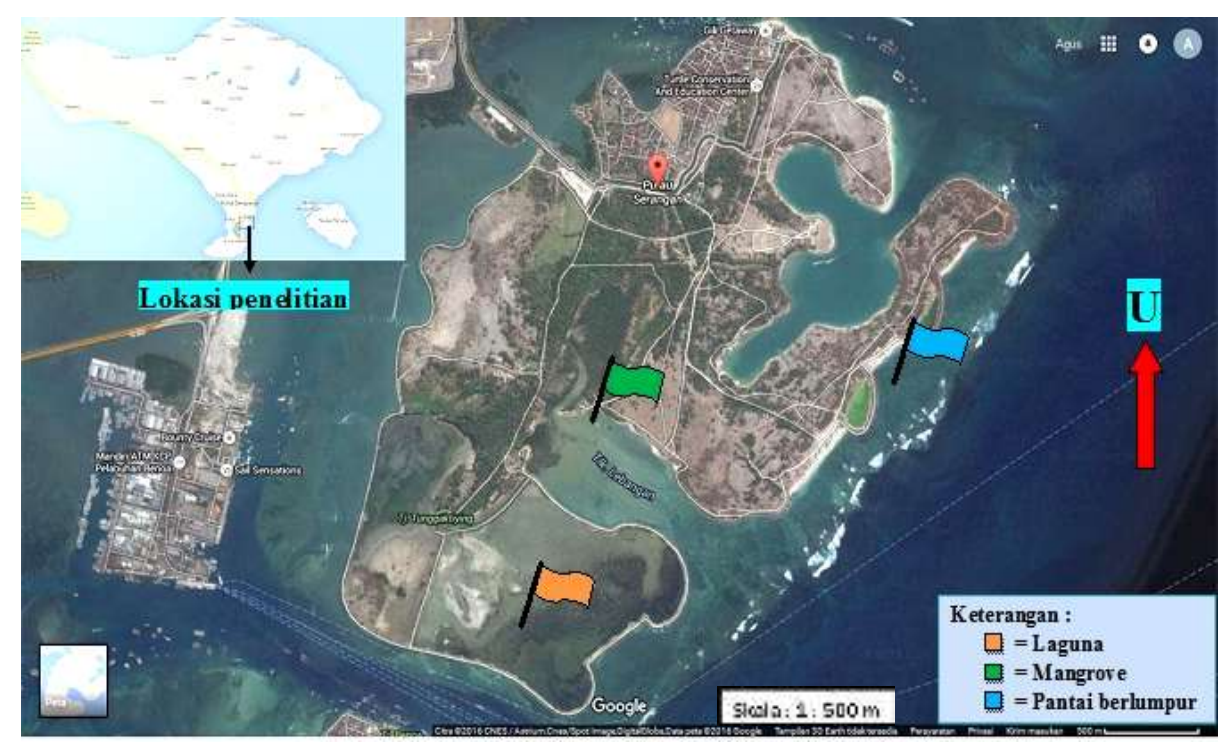

Gambar 1. Peta lokasi penelitian di Pulau Serangan 


\section{HASIL}

Hasil pengamatan aktivitas harian burung kuntul kecil pada habitat laguna didapatkan aktivitas yang paling mendominasi adalah foraging (pagi : 50,15\%, siang : 46,62\%, sore : 49,63\%), sedangkan aktivitas yang paling sedikit dilakukan adalah agonistik (pagi : $0,12 \%$, siang : $0 \%$, sore : $0,15 \%$ ) (Gambar 2).

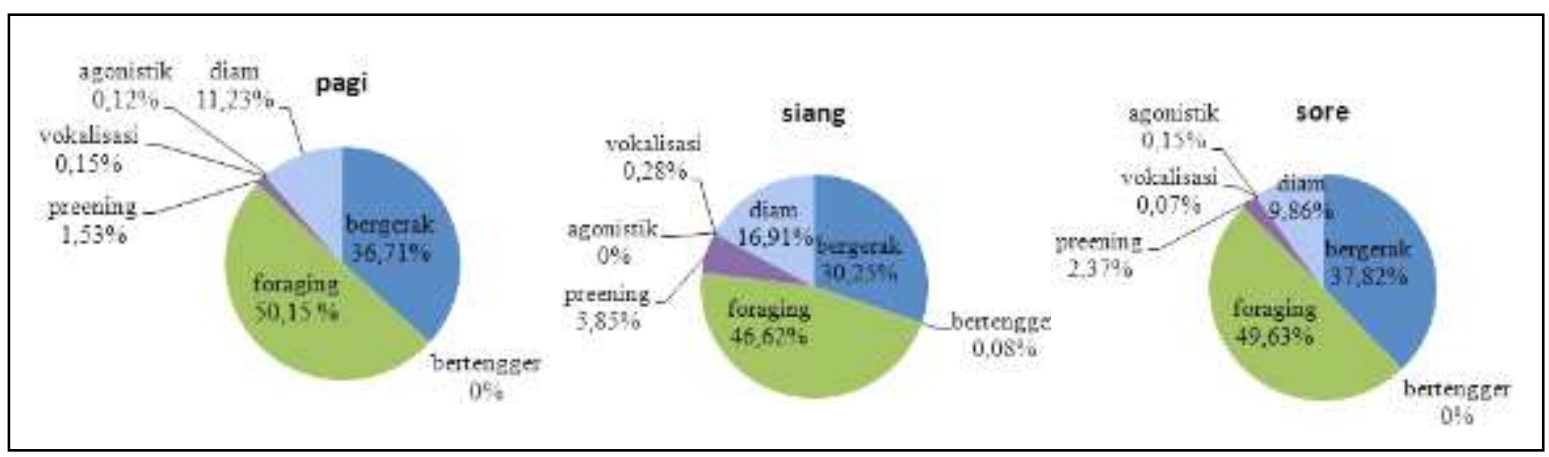

Gambar 2. Rata - rata aktivitas harian burung kuntul kecil pada habitat laguna

Aktivitas harian burung kuntul kecil pada habitat mangrove didominasi oleh foraging (pagi : $52,46 \%$, siang : 41,60\%, sore : 50,83\%), sedangkan aktivitas yang paling sedikit dilakukan adalah agonistik (pagi : 0,32\%, siang : $0,08 \%$, sore : $0,20 \%$ ) (Gambar 3).

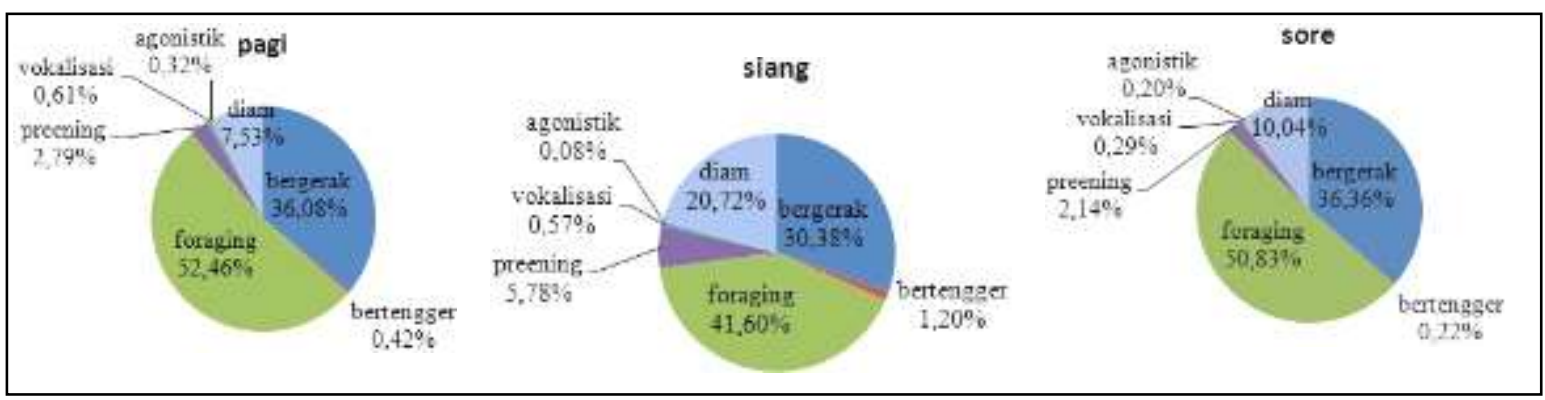

Gambar 3. Rata - rata aktivitas harian burung kuntul kecil pada habitat mangrove

Pada habitat pantai lumpur aktivitas yang paling mendominasi adalah foraging (pagi : 50,18\%, siang : $42,70 \%$, sore : 49,65\%), sedangkan aktivitas yang paling sedikit dilakukan adalah aktivitas agonistik (pagi : $0,21 \%$, siang : $0,02 \%$, sore : 0,24\%) (Gambar 4).

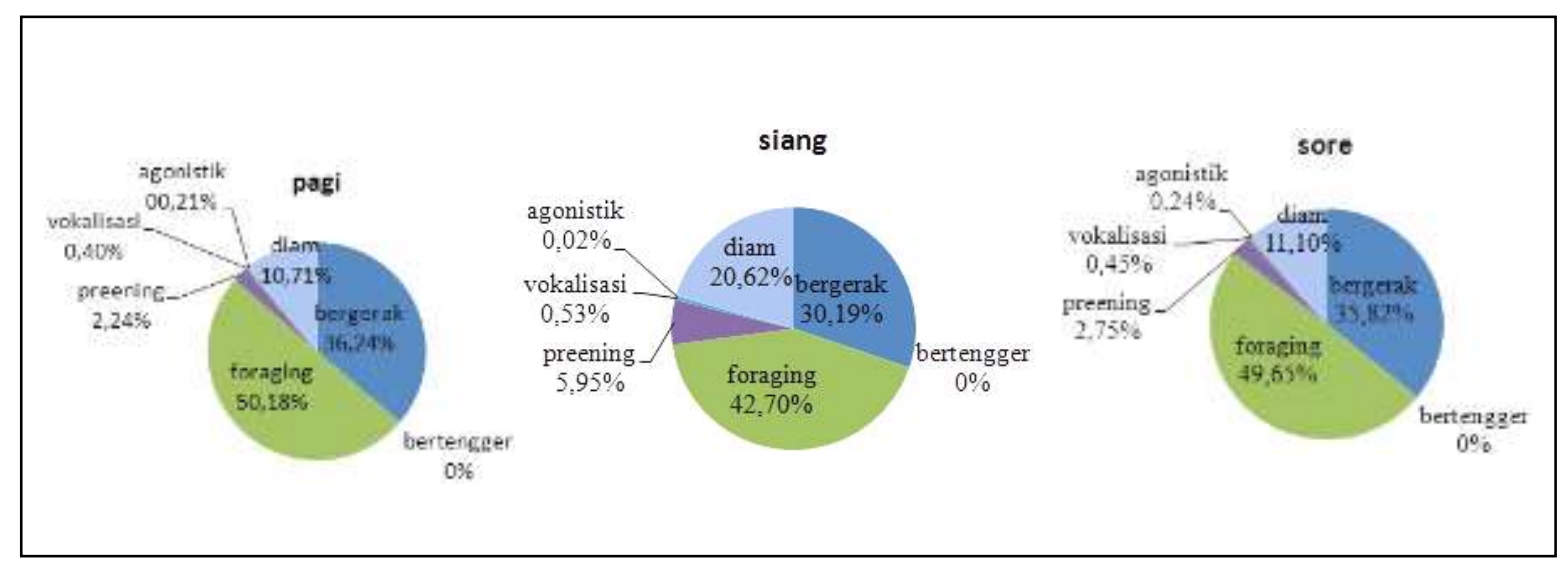

Gambar 4. Rata - rata aktivitas harian burung kuntul kecil pada habitat pantai lumpur 


\section{PEMBAHASAN}

Dari hasil pengamatan pada ketiga tipe habitat, persentase aktivitas bergerak paling tinggi dilakukan pada pagi hari dan sore hari. Hal tersebut disebabkan oleh karena pada pagi hari merupakan waktu aktif bagi burung kuntul kecil untuk mencari makan, dan pada sore hari burung akan melakukan pergerakan kembali untuk mensuplai makanan yang digunakan untuk menyimpan energi (Ardley, 1985). Pada siang hari, aktivitas bergerak sedikit menurun akibat suhu lingkungan yang mulai tinggi dan burung lebih banyak beristirahat atau berjemur. Waktu hujan, burung akan mengurangi aktivitas bergerak dan foraging, burung akan lebih banyak melakukan aktivitas bertengger dan preening untuk meningkatkan suhu tubuh (Vithrayanti, 2005).

Persentase aktivitas foraging paling tinggi dilakukan pada waktu pagi hari. Ini sesuai dengan pernyataan Ford (1989) yaitu umumnya pada pagi hari sampai tengah hari merupakan saat yang paling optimum untuk mencari makan. Pada pagi hari pakan burung seperti serangga dan ikan juga aktif. Pada siang hari, persentase aktivitas foraging di ketiga habitat menurun karena pada siang hari burung lebih banyak istirahat seperti bertengger atau hanya berdiam diri sambil berjemur. Menurut Ardley (1985) tingginya temperatur lingkungan pada siang hari juga berpengaruh terhadap aktivitas burung, semakin rendah suhu lingkungan, aktivitas yang dilakukan semakin tinggi sedangkan semakin tinggi suhu lingkungan aktivitas yang dilakukan semakin rendah. Namun jika suhu terlalu rendah atau mencapai minus, burung akan berpindah tempat mencari makan ke tempat lain dengan suhu yang lebih hangat. Pada sore hari, persentase aktivitas foraging kembali meningkat. Burung kembali melakukan aktivitas foraging setelah istirahat pada siang hari untuk mensuplai kebutuhan makannya yang berguna untuk menyimpan energi sepanjang malam (Ardley, 1985).

Pada habitat mangrove, persentase aktivitas foraging paling tinggi dibandingkan tipe habitat lainnya, karena makanan yang terdapat di daerah mangrove lebih melimpah dan beragam, diantaranya dari kelompok crustacea, molusca, dan ikan. Mangrove juga merupakan tempat bertelur, memijah dan tempat berlindung bagi larva ikan dan udang (Feller dan Sitnik, 1996). Hal ini juga terkait dengan ukuran kaki dari kuntul kecil yang memiliki kaki pendek serta dapat mencari makan di substrat yang lebih padat serta perairan yang dangkal.

Aktivitas burung juga berpengaruh dengan kondisi pasang surut air laut. Saat surut burung akan banyak berdatangan di tiga habitat ini untuk melakukan aktivitas mencari makan, sedangkan saat pasang burung kuntul kecil akan lebih banyak beristirahat di pohon atau mencari makan di tempat lain dengan level air yang lebih rendah.

Kuntul kecil melakukan aktivitas foraging yaitu dengan menunggu mangsanya datang, berjalan atau berlari dan mengais - ngais (Ginting, 2005). Selain itu, menurut penelitian Dalem dkk. (2011) di kawasan Lagoon, Nusa Dua dimana saat mengamati kuntul kecil pada pagi hari, beberapa burung terbang diatas laguna dan terbang menukik ke permukaan laguna untuk menangkap ikan. Hal ini serupa dengan yang dilaporkan oleh Mackay (1967) dalam Dalem dkk. (2011) bahwa di kolam di Moitaka, Papua New Guinea, ikan - ikan sangat banyak muncul di permukaan air sehingga air terlihat seperti mendidih kemudian burung kuntul kecil ini terbang diatas kolam dan menukik dengan kecepatan rendah dan menangkap ikan di kolam tersebut.

Dalam aktivitas mencari makan, kuntul kecil biasanya bersama dengan jenis burung lain yang dekat dengan tempat kuntul kecil mencari makan diantaranya pecuk padi hitam (Phalacrocorax sulcirostris), pecuk padi belang (Microcarbo melanoleucos), kuntul besar (Egretta alba), kuntul kerbau (Bubulcus ibis), kuntul perak (Egretta intermedia), blekok sawah (Ardeola speciosa), gajahan (Numenius sp.), trinil pantai (Actitis hypoleucos), cerek kalung kecil (Charadrius dubius), cerek pasir besar (Charadrius leschenaultii), cerek jawa (Charadrius javanicus) dan cangak abu (Ardea purpurea). Bentuk interaksi interspesies yang terjadi antara kuntul kecil dengan pecuk padi hitam atau pecuk padi belang adalah interaksi kooperasi yaitu bersifat saling membantu antara keduanya, dimana pecuk mencari makan dengan cara menyelamkan tubuhnya yang akan membuat ikan naik ke permukaan, sedangkan interaksi dengan jenis burung lain bersifat tidak menguntungkan dan juga tidak merugikan.

Aktivitas bertengger hanya dilakukan pada habitat mangrove sedangkan di tipe habitat laguna dan pantai lumpur tidak menunjukkan adanya aktivitas bertengger, karena kondisi lingkungan tempat pengamatan berlangsung, dimana di daerah mangrove lebih banyak terdapat pepohonan mangrove yang memiliki dahan sebagai tempat bertengger dibandingkan di daerah laguna dan pantai lumpur yang lebih sedikit terdapat pepohonan.

Aktivitas bertengger sering dilakukan pada siang hari atau saat suhu lingkungan mulai tinggi. Burung akan bertengger pada kayu atau dahan pohon yang berdaun cukup rimbun dengan mata tidak tertutup untuk mengamati keadaan sekitar sehingga tetap waspada terhadap predator (Takandjanji dan Mite, 2008). Saat cuaca mendung, burung akan melakukan 
aktivitas bertengger namun lebih sedikit dibanding saat cuaca panas, burung akan cenderung mencari dahan pohon dengan daun yang lebih rimbun untuk berteduh.

Aktivitas preening merupakan aktivitas yang dilakukan burung untuk membersihkan, merawat, dan memelihara bulu mereka. Ada beberapa cara untuk melakukannya yaitu menelisik bulunya dengan paruh, menggaruk - garuk tubuhnya dengan kaki, dan menggosok - gosokkan paruh mereka ke suatu benda seperti batu ataupun kayu (Wahyuni, 2011). Aktivitas preening merupakan aktivitas yang sangat efisien bagi burung untuk merawat bulu serta pertahanan diri dari ektoparasit (Clayton dan Cotgreave, 1994).

Dari hasil pengamatan didapatkan bahwa aktivitas preening paling tinggi dilakukan pada siang hari, karena pada umumnya burung melakukan aktivitas ini pada siang hari atau saat suhu mulai tinggi yaitu saat burung selesai melakukan aktivitas bergerak dan foraging. Pada pagi hari dan sore hari persentase aktivitas preening juga cukup tinggi, mungkin karena burung merasa ada sesuatu yang menempel ditubuhnya dan melakukan aktivitas tersebut untuk membersihkannya.

Aktivitas vokalisasi merupakan aktivitas mengeluarkan suara yang dilakukan burung untuk tujuan tertentu. Dari ketiga tipe habitat, persentase aktivitas vokalisasi tidak menunjukkan adanya perbedaan. Umumnya tidak ada waktu tertentu bagi burung kuntul kecil mengeluarkan suara, itu terjadi tergantung keadaan di lingkungan tempat melakukan aktivitas. Saat pengamatan, terlihat beberapa kali pada habitat mangrove, salah satu burung kuntul kecil mengeluarkan suara. Burung ini merasa tempatnya mencari makan didatangi oleh burung lain entah itu dari kelompok burung tersebut atau kelompok burung lain. Menurut Strange (2000), pada dasarnya kuntul kecil merupakan burung yang pendiam. Burung ini hanya mengeluarkan suaranya untuk menandakan suatu kejadian sebagai tanda bahaya, saat ada kompetitor atau predator datang serta untuk menarik perhatian pasangan saat akan

\section{KESIMPULAN}

Dapat disimpulkan bahwa dari ketiga tipe habitat (laguna, mangrove, dan pantai lumpur), aktivitas yang paling mendominasi adalah aktivitas foraging, dikarenakan umumnya burung lebih banyak menghabiskan waktunya untuk mencari makan (foraging). Aktivitas dengan persentase yang paling rendah di ketiga tipe habitat adalah aktivitas agonistik. Rendahnya persentase aktivitas ini karena dilakukan hanya saat burung dalam keadaan terancam atau kompetisi dalam mencari makan atau pasangan kawin. kawin. Hal tersebut sesuai dengan pernyataan Campbell dkk. (2004) dimana fungsi dari vokalisasi burung untuk mengirimkan informasi kepada burung lain. Bagi anakan burung, vokalisasi berguna untuk meminta makanan pada induknya.

Aktivitas agonistik merupakan aktivitas yang paling rendah dilakukan oleh burung kuntul kecil selama pengamatan berlangsung. Umumnya aktivitas ini terjadi jika ada ancaman atau interaksi yang bersifat kompetitif. Namun ini merupakan semacam bioindikator dimana semakin tinggi kompetisi di suatu tempat itu menandakan bahwa semakin sedikit makanan yang terdapat di areal tersebut, dan sebaliknya semakin rendah kompetisi di suatu tempat itu menandakan masih melimpah makanan di areal tersebut. Semakin banyaknya keberadaan burung di suatu tempat menandakan bahwa kawasan tersebut masih baik keadaan lingkungannya, namun semakin sedikit burung di suatu tempat kawasan tersebut keadaannya memburuk (Dono, 2013). Menurut Campbell (2002), aktivitas agonistik juga terjadi saat mencari pasangan untuk kawin. Burung akan menegakkan dan membesarkan postur tubuhnya atau dengan membesarkan suaranya untuk membuat takut pesaingnya sampai salah satu individu menyerah atau pergi dari daerah tersebut.

Aktivitas berdiam diri dilakukan di sela-sela melakukan aktivitas bergerak, burung akan melakukan pergerakan kemudian diam, bergerak kembali kemudian diam kembali. Aktivitas berdiam diri terkadang dilakukan sambil menaikkan kaki atau berdiri sambil membuka sayap, ini diduga burung ini sedang berjemur atau istirahat di sela - sela aktivitasnya. Didapatkan pada ketiga tipe habitat, aktivitas berdiam diri paling tinggi persentasenya pada periode waktu siang hari. Ini kemungkinan burung kuntul kecil beristirahat sejenak setelah melakukan aktivitas untuk meregangkan sayap ataupun berjemur sambil melakukan preening.

\section{DAFTAR PUSTAKA}

Altmann, J. 1974. Observational Study of Behavior; Sampling Methods Behavior 49: 227- 267.

Ardley, N. 1985. Burung. Cetakan ke -5. Diterjemahkan oleh Tatang Djuhanda. Widyadara. Jakarta.

Campbell, J.B. 2002. Biologi. Erlangga. Jakarta.

Campbell, N. A., B. Reece, L. G. Mitchell. 2004. Biologi Edisi Ke-5 Jilid III. Diterjemahkan oleh Wasmen Manalu. Erlangga. Jakarta.

Clayton, D. H. Dan Cotgreave, P. 1994. Comparative Analysis of Time Spent Grooming by Bird in Relation to Parasite Load. Behaviour 131 (3-4): 171 - 187. 
Dalem, A. A. G. R. dan J. N. Subagio. 2016. Burung sebagai Atraksi Ekowisata di Kawasan Jatiluwih, Tabanan, Bali. Poster dalam Seminar Nasional Senastek III Universitas Udayana, Bali di Hotel The Patra Tuban, Bali. Tanggal 15 Desember 2016.

Dalem, A. A. G. R. dan J. N. Subagio. 2016. Jenis - Jenis Burung Yang Ditemukan di Jatiluwih, Tabanan, Bali. Prosiding Seminar Nasional dan Teknologi FMIPA Universitas Udayana, Di Kampus Unud Bukit Jimbaran. Tanggal 19 Oktober 2016.

Dalem, A. A. G. R., I K. Muksin, S. K. Sudirga dan I. B. M. Suaskara. 2003. Burung Sebagai Atraksi Ekowisata di Kawasan Pariwisata Nusa Dua, Bali. J. Lingkungan Hidup Bumi Lestari 3(2): 12-33.

Dalem, A. A. G. R., I. N. Widana dan I. A. Trisna Eka Putri. 2014. Burung Sebagai Atraksi Ekowisata di Kawasan Pariwisata Ubud, Bali. J. Bumi Lestari 14 (2): $125-132$.

Dalem, A. A. G. R., S. K. Sudirga., and S. Burgin. 2011. Birds of Nusa Dua Sewage Ponds, Bali and an Unusual Foraging Behavior of Egret. Kukila 15 : 66 74. Bali

Dono, T. 2013. Burung Sebagai Indikator Kawasan Konservasi. Available at nationalgeographic.co.id/berita/2013/o7/burungsebagai-indikator-kawasan-konservasi. Opened on : 17 Januari 2017.

Elfidasari, D dan Junardi. 2005. Keragaman Burung Air Di Kawasan Hutan Mangrove Peniti, Kabupaten Pontianak. Biodiversitas 7 (1): $63-66$.

Feller, C. I., dan Sitnik, M. 1996. Mangrove Ecology : A Manual fr a Field Course. Smithsonian Instituion. Washington.

Ford, H. A. 1989. Ecology of Bird. An Australian Perspective. Surrey Beatty \& Sons Pty Limited. Australia.

Ginting, M. 2005. Aktivitas Harian Burung Kuntul Besar (Egretta alba) di BTDC Lagoon, Nusa Dua. Jurusan Biologi Fakultas Matematika dan Ilmu Pengetahuan Alam. Universitas Udayana. Bali.

Mackay, R.D. 1967. Birds Catching Fish in Papua. Australian Bird Watcher. $3: 46-48$.

MacKinnon, J., K. Phillips., B. van Balen. 2010. Burung - Burung di Sumatera, Jawa, Bali dan Kalimantan. Penterjemah: W. Rahardjaningtrah; A. Adikerana; P. Martodiharjo; E, K. Supardiyono; B. van Balen. Puslitbang Biologi-LIPI/Birdlife International Programme. Bogor.

Strange, M. 2000. A Photographic Guide to Birds of Malaysia and Singapore Including Southeast Asia, The Philippines and Borneo. Periplus. Singapore.

Sudarsana, I. W. 2006. Perilaku Makan Burung Kuntul Kecil (Egretta garzetta) di The Mangrove Information Centre Suwung Denpasar Bali. Jurusan Biologi Fakultas Matematika dan Ilmu Pengetahuan Alam. Universitas Udayana. Bali.
Takandjanji, M. dan M. Mite. 2008. Perilaku Burung Beo Alor di Penangkaran Oilsonbai, Nusa Tenggara Timur. Buletin Plasma Nutfah 14 (1).

Trialfhianty, T.I. 2013. Kondisi Padang Lamun Pulau Serangan, Bali. Bali.

Vithrayanti, P. A. W. 2005. Tingkah Laku Burung Jalak Bali (Leucopsar rothschildi) Di Bali Bird Park Singapadu Gianyar. Jurusan Biologi FMIPA UNUD. Bali.

Wahyuni, E. 2011. Perilaku Harian Burung Cendrawasih Kuning Besar (Paradisaea apoda Linnaeus, 1758) Di Bali Bird Park Gianyar, Bali. Jurusan Biologi FMIPA UNUD. Bali. [Skripsi]. 